\title{
NOTES ON THE BIOLOGY OF Trypoxylon (Trypargilum) opacum BRÈTHES (HYMENOPTERA; CRABRONIDAE) IN SOUTHERN BRAZIL
}

\author{
BUSCHINI, M. L. T. and WOLFF, L. L. \\ Depto de Biologia, UNICENTRO, Rua Presidente Zacarias, 875, 85010-990, Guarapuava, PR, Brazil \\ Correspondence to: Maria Luisa Tunes Buschini, Depto de Biologia, UNICENTRO, Rua Presidente Zacarias, \\ 875, CEP 85010-990, Guarapuava, PR, Brazil, e-mail: isatunes@yahoo.com.br \\ Received September 27, 2004 - Accepted May 4, 2005 - Distributed August 31, 2006
}

(With 6 figures)

\begin{abstract}
The present study investigated the abundance, seasonality and various life-history traits of Trypoxylon (Trypargilum) opacum. Using trap-nests, 320 nests of T. opacum were collected in the Parque Municipal

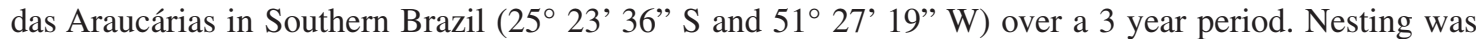
more frequent during the warm season. Nests consisted of a linear series of 1 to 8 brood cells separated by mud partitions, usually followed by an empty vestibular cell and final-closure mud plug. Brood cells were most commonly provisioned with spiders of the family Araneidae. Sex-ratio was strongly female biased, 3.4:1 females:males. Natural enemies attacking nests T. opacum included chrysidids, ichneumonids, sarcophagids, bombyliids and ants.
\end{abstract}

Keywords: Crabronidae, Trypoxylon, biology, Hymenoptera.

\section{RESUMO}

\section{Notas sobre a biologia de Trypoxylon (Trypargilum) opacum (Hymenoptera; Crabronidae) no Sul do Brasil}

Este estudo investigou a abundância, a sazonalidade e a história de vida Trypoxylon (Trypargilum) opacum. Utilizando-se ninhos armadilhas por um período de 3 anos, foram coletados 320 ninhos de T. opacum no

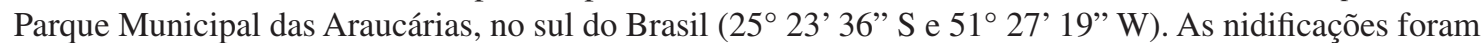
mais freqüentes na estação quente. Os ninhos são formados por uma série linear de células, separadas por partições de barro, cujo número variou de 1 a 8 . Eles apresentaram, normalmente, uma célula vestibular, e um batoque de fechamento na entrada. As células foram aprovisionadas, na maioria das vezes, com aranhas da família Araneidae. A razão sexual tendeu às fêmeas, 3,4:1 fêmeas:machos. Chrysididae, Ichneumonidae, Sarcophagidae, Bombiliidae e formigas foram os seus principais inimigos naturais.

Palavras-chave: Crabronidae, Trypoxylon, biologia, Hymenoptera.

\section{INTRODUCTION}

Crabronid wasps are solitary predators, preying upon a broad spectrum of insects and spiders that are used to feeding on their larvae. Nesting habits vary considerably within the family from nests in the ground or inside pre-existing burrows to free nests built of mud or vegetal materials, which are attached to a variety of substrates (Bohart \& Menke, 1976; Menke \& Fernandez,1996).
Trypoxylon is a particularly diverse genus within the Crabronidae. Despite showing a worldwide distribution, a considerable part of its diversity is concentrated in the Western hemisphere, particularly in South and Central Americas. The subgenus Trypargilum is restricted to the New World (Bohart \& Menke, 1976).

Many species groups and complexes of Trypargilum appear to have several distinctive 
features such as their nest architecture, cocoon morphology and prey preference (Krombein, 1967; Coville, 1982). Some of their species build mud nests and others use pre-existing cavities. Since theses wasps are solitary, each female builds its nest and supplies it with spiders (Bohart \& Menke, 1976).

According to Genaro et al. (1989), it is not surprising to find prey belonging to genera and species of spiders not yet described inside the nests. Moreover, they can differ from the number and percentage of spider species collected (Camillo et al., 1993; Camillo et al., 1994). According to some researchers, one of the most important pieces of information derived from studies regarding the biology of Crabronidae is related to the kind of prey that these wasps use to feed their brood on (Camillo \& Brescovit, 1999).

Many studies concerning the biology of Trypoxylon have been undertaken in Brazil using trap nests (Perez-Maluf, 1993; Camillo et al., 1993; Camillo et al., 1994; Camillo et al., 1996; Assis \& Camillo, 1997; Camillo \& Brescovit, 1999; Camillo \& Brescovit, 2000; Niesing, 2003). According to Krombeim (1967) and Garófalo (2000), this type of trap can provide some information about the diversity of the species and about some aspects of its biology, since this is a simple methodology and considers its power in sampling only the species that occur in the study area, avoiding those that are passing through it. Moreover, trap-nests can be easily transported and observed in the laboratory.

Since little is known about the natural history of Trypoxylon opacum, the aim of this paper is to report on several aspects of its biology.

\section{MATERIALS AND METHODS}

\section{Study area}

This study was carried out in the Parque Municipal das Araucárias in the municipality of Guarapuava, state of Paraná, Southern Brazil (25 $23^{\prime} 36^{\prime \prime} \mathrm{S}$ and $51^{\circ} 27^{\prime} 19^{\prime \prime} \mathrm{W}, 1,120 \mathrm{~m}$ above sea level). This region is known for its moderate seasonality, with a cold/wet season, where in the warmest months the average temperature is less than $22{ }^{\circ} \mathrm{C}$. Hard frosts are frequent and often severe.

\section{Sampling program}

T. opacum nests were obtained using trapnests of $0.7,1.0$, and $1.3 \mathrm{~cm}$ in diameter and $8.0 \mathrm{~cm}$ in depth. Each nest was placed $1.5 \mathrm{~m}$ above the ground and was inspected every two weeks. In each inspection, all occupied nests were immediately replaced with empty traps of the same diameter and then brought to the laboratory to investigate their contents. If eggs and/or larvae are present, the nest is sealed again so that the life-cycle can be completed until the adults emerge. Spiders bearing wasp eggs or recently hatched larvae were removed, weighed and placed back inside their cells of origin. Recently emerged adults were carefully removed and weighed. Cocoon and cell volumes were calculated using a cylinder formula.

Collections were carried out over 3 years, which were divided into two periods, from April, 2000 to April, 2002 and from December, 2001 to December, 2003. In the first period collections were concentrated in a very heterogeneous site which included Araucaria forests, swamps and grasslands. In each habitat, 24 points were marked $2.5 \mathrm{~m}$ apart from each other along two perpendicular transects. Two of these points were randomly chosen in each transect to harbor three $1 \mathrm{~cm}$ trap-nests. In the second period, 2 areas were sampled in each habitat, with 2 transects per area and 4 sampling stations per transect. Each sampling station had 12 trap nests, four of which had an opening diameter (0.7, 1.0 and $1.3 \mathrm{~cm}$, respectively), for an overall total of 576 traps. Humidity and temperature of each habitat were measured throughout both sampling periods.

\section{Data analysis}

Mann-Whitney's U test was used to test the null hypothesis relating nest architecture, premature development time and adult body mass.

The sex ratio was calculated by the ratio between number of females and number of males, and the chi-square test was used to check the extent by which the observed sex ratio deviated from the expected frequency ( 1 female: 1 male).

\section{RESULTS}

\section{Seasonality and nesting activity in different habitats}

A total of 320 nests was collected during this study; 50 during the first sampling period, and 270 during the second, respectively. Nests were most commonly collected during the spring, summer 
and early autumn. During the first sampling period, nests were more abundant during October and November, with this trend shifting to January and February during the second sampling period (Figs. 1 and 2).

Throughout the first period, T. opacum built more nests in the swamp $(n=31)$ than in the grassland $(\mathrm{n}=19)$. However, during the second sampling period, an opposite trend was observed, with more nests being built in the grassland $(\mathrm{n}=163)$ as compared to the swamp $(\mathrm{n}=107)$. No nest was built in the Araucaria forest during both sampling periods (Figs. 3 and 4). This was the wettest habitat and had the lowest temperature.

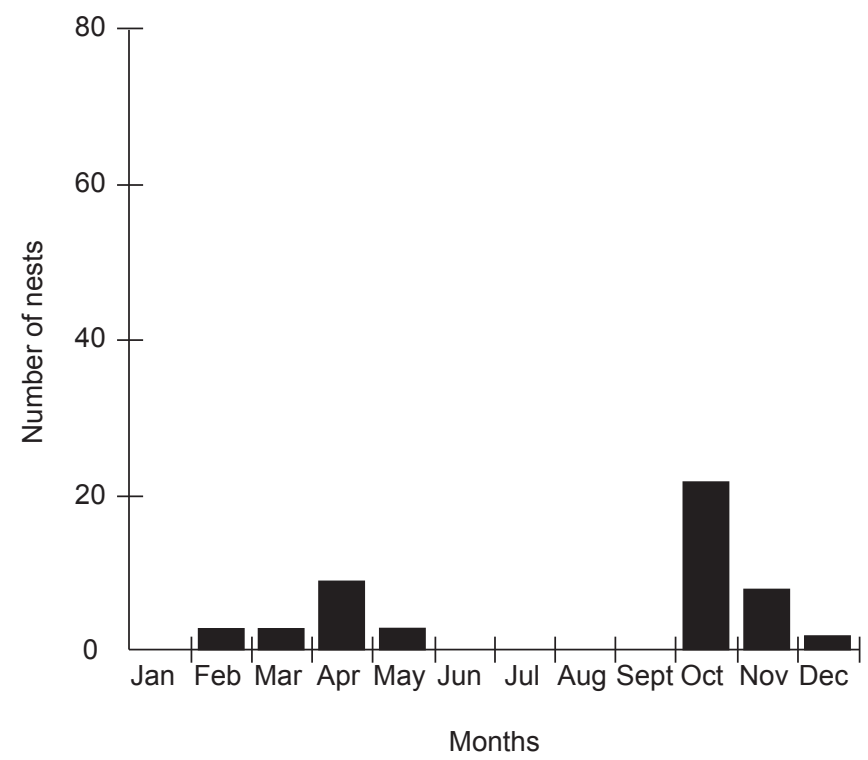

Fig. 1 - Seasonal variation in the number of nests of Trypoxylon opacum obtained monthly from April, 2000 to April, 2002 (first sampling period).

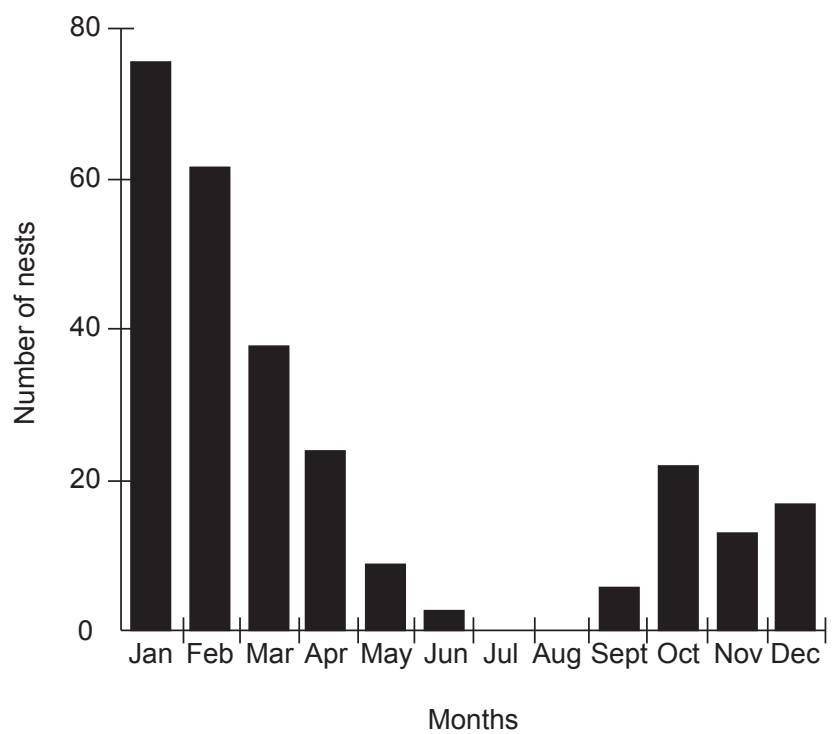

Fig. 2 - Seasonal variation in the number of nests of Trypoxylon opacum obtained monthly from January, 2002 to December, 2003 (second sampling period). 


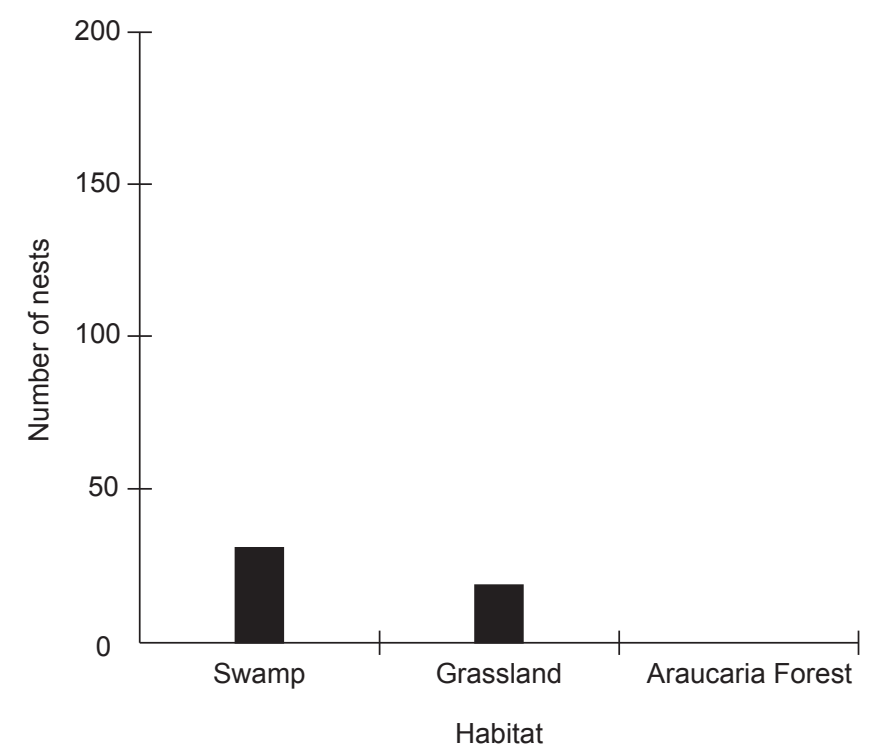

Fig. 3 - Number of nests of Trypoxylon opacum obtained in different habitats from April, 2000 to April, 2002.

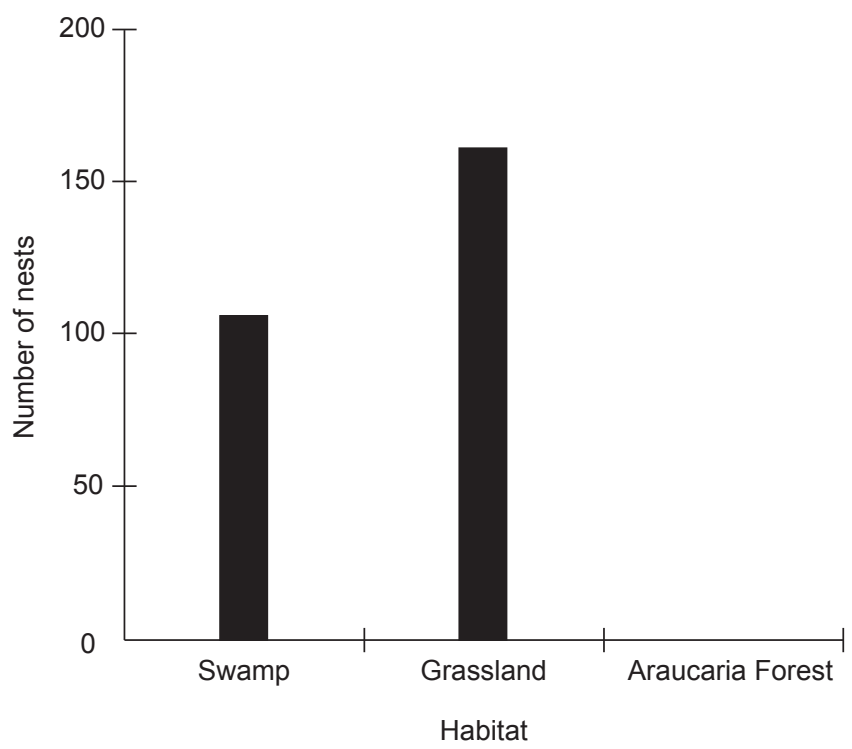

Fig. 4 - Number of nests of Trypoxylon opacum obtained in different habitats from January, 2002 to December, 2003.

On the other hand, temperature and humidity were almost the same in the swamp and in the grassland (Figs. 5 and 6).

Although trap-nests of $1.0 \mathrm{~cm}$ in diameter were extensively accepted by the wasps during the first sampling period, when no other choice of diameter was possible ( $\mathrm{n}=50$ nests), the availability of alternative diameters in the second sampling indicated that $T$. opacum preferred nests of $0.7 \mathrm{~cm}$ in diameter $(\mathrm{n}=258)$ over $1.0 \mathrm{~cm}$ trap nests $(\mathrm{n}=11)$. Only one $1.3 \mathrm{~cm}$ trap-nest was found occupied, which was attacked by parasitoids. 


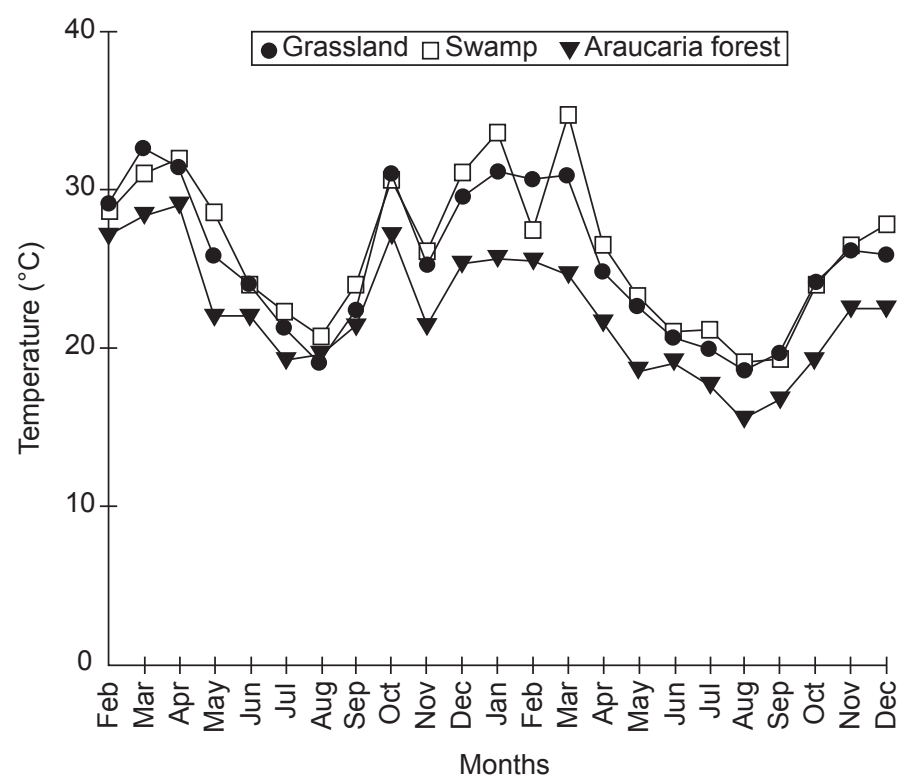

Fig. 5 - Air temperature in different habitats from February, 2002 to December, 2003.

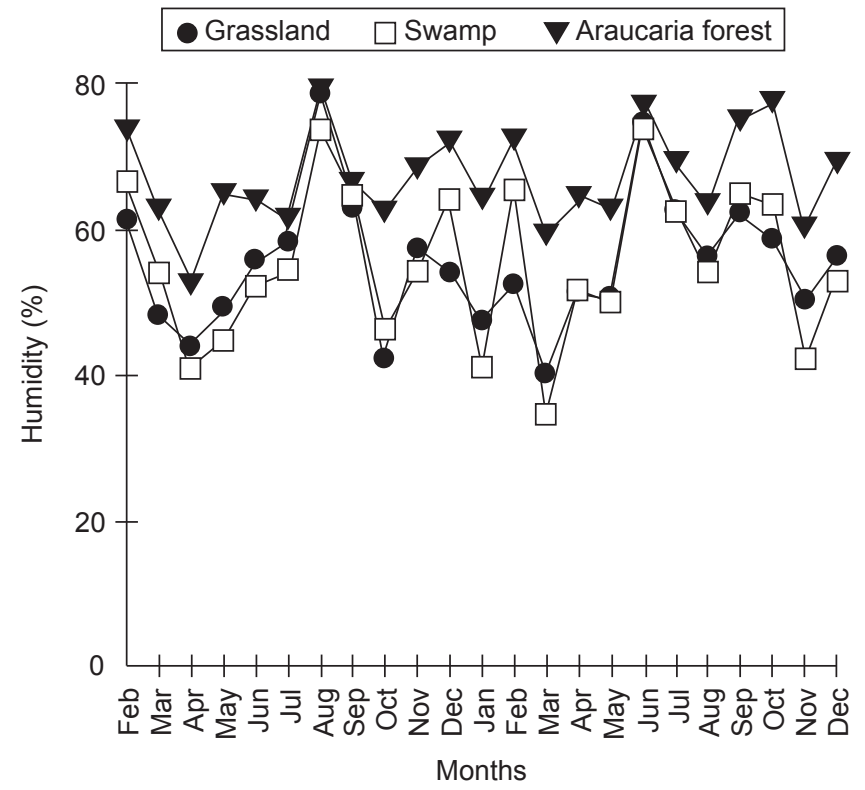

Fig. 6 - Air humidity conditions in different habitats from February, 2002 to December, 2003.

\section{Nest architecture}

T. opacum nests consisted of 1 to 8 cells forming a linear series. Each cell was provisioned with paralyzed spiders and was sealed with a mud partition that was rough and convex on the inner surface and smooth and concave on the outer surface. At times, the outer partition was simple and thicker than the inner one. No intercalar cell was observed.

The diameter of the trap-nest did not affect most aspects of the architecture of the T. opacum nest (Unless otherwise stated, all comparisons 
between nest-traps of different diameters are henceforth reported for 0.7 and $1.0 \mathrm{~cm}$ trap-nests). No significant difference was found in nest length (median $=6.7 \mathrm{~cm}$ and $6.4 \mathrm{~cm}$, Mann-Whitney's $\mathrm{U}=5,195.00 ; \mathrm{P}=0.149$ ), the number of vestibular cells (Mann-Whitney's $\mathrm{U}=855.50 ; \mathrm{P}=0.254$ ) and their length (Mann-Whitney $=1,412.00$; $\mathrm{P}=0.245$ ). The average thickness of the outer plug was also similar between trap-nests (median $=0.20$ and $0.23 \mathrm{~cm}$ for 0.7 and $1.0 \mathrm{~cm}$ trap-nests). Within each trap-nest diameter, no difference in male and female cell volume was observed. However, the average number of provisioned cells $(\overline{\mathrm{X}}=4.2$ and 5.1 for 0.7 and $1.0 \mathrm{~cm}$ trap-nests, Mann-Whitney's $\mathrm{U}=8,481.50 ; \mathrm{P}<0.000)$ and their length (MannWhitney's $\mathrm{U}=1000,722.00 ; \mathrm{P}<0.000)$ were significantly larger in $1.0 \mathrm{~cm}$ trap-nests than in $0.7 \mathrm{~cm}$ trap-nests, as well as the average volume of male and female cells from different trap-nests diameter (Tables 1 and 2).

\section{Life-history and sex ratios}

Two types of life cycles were observed in T. opacum; direct development without diapause and delayed development with diapause in the winter. In the case of delayed development, development time was similar for both sexes, regardless of the type of trap-nest (Tables 2 and 3). The females developed sooner than males $(\overline{\mathrm{X}}=228.4$ and 232.6 days for females in 0.7 and $1.0 \mathrm{~cm}$ nest traps, $\overline{\mathrm{X}}=234.4$ and 238.3 days for males in 0.7 and $1.0 \mathrm{~cm}$ nest traps).

In the direct development, significant differences in development time between sexes were detected, depending on the diameter of the trap-nest. Mean male development in the $0.7 \mathrm{~cm}$ trap nest was 42.5 and was significantly shorter than females $(\bar{X}=44.8)$. In $1.0 \mathrm{~cm}$ trap-nest, however, development time was similar for both sexes $(\bar{X}=46.2$ for females, $\bar{X}=48.9$ days for males, Tables 2 and 3).

Detailed daily observations enabled us to measure the duration of the different phases of development in both trap-nests. In $0.7 \mathrm{~cm}$ trapnests, measurements included the average number of days for the ecclosion of larvae $(\overline{\mathrm{X}}=2.0 \pm 0.00$; $\mathrm{n}=2)$, to complete feeding $(\overline{\mathrm{X}}=4.46 \pm 2.45$; $\mathrm{n}=11)$, to spin the cocoon $(\overline{\mathrm{X}}=2.74 \pm 0.89$; $\mathrm{n}=65$ ), to pupate under direct development $(\bar{X}=45.13 \pm 7.54 ; n=30)$ and to pupate under delayed development $(\bar{X}=226.82 \pm 27.31$; $\mathrm{n}=27$ ). Similar measurements were taken in $1.0 \mathrm{~cm}$ trap-nests, including the average number of days for the ecclosion of larvae $(\bar{X}=1.9 \pm 0.74$; $\mathrm{n}=10)$, to complete feeding $(\overline{\mathrm{X}}=6.50 \pm 0.71$; $\mathrm{n}=2)$, to spin the cocoon $(\overline{\mathrm{X}}=2.26 \pm 0.54$; $\mathrm{n}=23$ ), to pupate under direct development $(\overline{\mathrm{X}}=47.67 \pm 2.12 ; \mathrm{n}=9)$ and to pupate under delayed development $(\bar{X}=211.25 \pm 54.30 ; n=4)$.

Sex ratio was strongly female-biased as 340 females and 100 males emerged (3.4 females: 1 male, significantly different from $1: 1$, $\chi^{2}=108.32$ d.f. $=1, \mathrm{P}<0.001$ ).

\section{Cocoon structure and adult weights}

Female and male cocoons are morphologically similar as they are shiny dark brown, brittle, cylindrical, the posterior end is rounded and the anterior end truncated without a median nipple. The anterior part is gray and more coarsely granular than the rest of the cocoon. All cocoon volumes of males and females were statistically different expect for female cocoons from nests of $0.7 \mathrm{~cm}$ when compared with male cocoons of nests of $1.0 \mathrm{~cm}$ diameter (Table 2).

The female weight was similar regardless of the trap-nest diameter. Median weights of these females (from nests of 0.7 and $1.0 \mathrm{~cm}$ diameter) and males from nests of $0.7 \mathrm{~cm}$ diameter, were statistically different (Tables 2 and 3).

\section{Mortality and natural enemies}

Mortality rates were similar in both trapnest diameters. Out of 660 provisioned cells in $0.7 \mathrm{~cm}$ trap-nests, $275(41.67 \%)$ failed to raise adults. In 1.0 trap-nests, 132 out of 283 $(46.64 \%)$ provisioned cells failed $\left(\chi^{2}=3.841\right.$; $0.25<\mathrm{P}<0.10)$. In $0.7 \mathrm{~cm}$ trap-nests, dead juveniles were observed in 86 cells $(31.27 \%)$, probably due to development failure that occurred in eggs $(1.82 \%)$, in larvae $(22.54 \%)$ or in pupa $(6.54 \%)$ stages. Only one cell had no egg or larvae $(0.36 \%)$. The most important mortality cause was the attack of parasitoids, recorded in 179 cells $(65.09 \%)$. Crysididae accounted for $35.64 \%$ of the attacks followed by Sarcophagidae (21.45\%), Ichneumonidae (5.09\%), Bombyliidae $(1.82 \%)$. Three deaths were caused by unidentified parasitoids $(1.09 \%)$. In ten cases $(3.64 \%)$, the adults died inside the nest as they emerged, but 
TABLE 1

Structure of nests of T. opacum in trap-nests of different diameters.

\begin{tabular}{|c|c|c|}
\hline & Trap-nest & Diameter \\
\hline Nest structure & 0.7 & 1.0 \\
\hline Total nest length & $\begin{array}{c}\bar{X}=6.7 \pm 1.79 \\
N=187 \\
\text { Median }=7.7\end{array}$ & $\begin{array}{c}\bar{X}=6.2 \pm 1.99 \\
N=49 \\
\text { Median }=6.4\end{array}$ \\
\hline Total number of cells & $\begin{array}{c}\bar{X}=4.2 \pm 1.70 \\
N=200 \\
\text { Median }=4.0\end{array}$ & $\begin{array}{c}\bar{X}=5.1 \pm 1.82 \\
N=59 \\
\text { Median }=5.0\end{array}$ \\
\hline Number of vestibular cells & $\begin{array}{c}\bar{X}=1.3 \pm 0.62 \\
N=132 \\
\text { Median }=1.0\end{array}$ & $\begin{array}{c}\overline{\mathrm{X}}=1.1 \pm 0.35 \\
\mathrm{~N}=15 \\
\text { Median }=1.0\end{array}$ \\
\hline $\begin{array}{l}\text { Number of provisioned } \\
\text { cells }\end{array}$ & $\begin{array}{c}\bar{X}=3.3 \pm 1.61 \\
N=200 \\
\text { Median }=3.0\end{array}$ & $\begin{array}{c}\bar{X}=4.7 \pm 1.82 \\
N=59 \\
\text { Median }=5.0\end{array}$ \\
\hline Vestibular cell length & $\begin{array}{c}\bar{X}=1.59 \pm 1.37 \\
N=171 \\
\text { Median }=1.21\end{array}$ & $\begin{array}{c}\bar{X}=1.18 \pm 0.77 \\
N=14 \\
\text { Median }=0.885\end{array}$ \\
\hline Provisioned cell length & $\begin{array}{c}\bar{X}=1.36 \pm 0.54 \\
N=646 \\
\text { Median }=1.24\end{array}$ & $\begin{array}{c}\bar{X}=1.02 \pm 0.26 \\
N=195 \\
\text { Median }=1.00\end{array}$ \\
\hline $\begin{array}{l}\text { Male cell } \\
\text { volume }(\mathrm{cm} 3)\end{array}$ & $\begin{array}{c}\bar{X}=0.458 \pm 0.121 \\
N=59 \\
\text { Median }=0.449\end{array}$ & $\begin{array}{c}\bar{X}=0.823 \pm 0.010 \\
N=8 \\
\text { Median }=0.801\end{array}$ \\
\hline $\begin{array}{l}\text { Female cell } \\
\text { volume }\left(\mathrm{cm}^{3}\right)\end{array}$ & $\begin{array}{c}\bar{X}=0.457 \pm 0.135 \\
N=201 \\
\text { Median }=0.464\end{array}$ & $\begin{array}{c}\overline{\mathrm{X}}=0.801 \pm 0.155 \\
\mathrm{~N}=66 \\
\text { Median }=0.809\end{array}$ \\
\hline Thickness of cell partition & $\begin{array}{c}\bar{X}=0.17 \pm 0.04 \\
N=623 \\
\text { Median }=0.165\end{array}$ & $\begin{array}{c}\bar{X}=0.19 \pm 0.05 \\
N=165 \\
\text { Median }=0.185\end{array}$ \\
\hline Thickness of closure plug & $\begin{array}{c}\bar{X}=0.19 \pm 0.06 \\
N=263 \\
\text { Median }=0.185\end{array}$ & $\begin{array}{c}\bar{X}=0.23 \pm 0.08 \\
N=49 \\
\text { Median }=0.235\end{array}$ \\
\hline
\end{tabular}

were not able to go through the mud partitions. Among failures in $1.0 \mathrm{~cm}$ trap nests, dead juveniles were observed in 77 cells $(58.33 \%)$, probably due to development failure that occurred in the larval $(34.85 \%)$ or in the pupal $(15.15 \%)$ stages. In 11 cells $(8.33 \%)$, no egg or larva was found. Fifty five cells $(41.67 \%)$ were attacked by parasitoids. Sarcophagidae accounted for $33.33 \%$ of the cases followed by Ichneumonidae (4.55\%), Crysididae $3.03 \%$ and ants $(0.76 \%)$.

\section{Collected prey}

Three to 16 spiders were found in each cell $(\bar{X}=10.81 \pm 3.69 ; \mathrm{n}=16)$. Spider weights per cell ranged between 20.50 to $107.90 \mathrm{mg}$ $(\overline{\mathrm{X}}=81.25 \pm 0.02 ; \mathrm{n}=11)$. Out of 816 spider species collected, 808 (99.02\%) belong to Araneidae (Bertrana rufostriata $(\mathrm{n}=29)$, Eutala $\mathrm{sp}_{4}$ $(\mathrm{n}=23)$, Eutala $\mathrm{sp}_{2}(\mathrm{n}=22)$, Eutala $\mathrm{sp}_{3}(\mathrm{n}=20)$, Eutala $\mathrm{sp}_{1}(\mathrm{n}=12)$, Alpaida $\mathrm{sp}_{2}(\mathrm{n}=16)$, Alpaida (10 juveniles), Mangora $\mathrm{sp}_{2}(\mathrm{n}=7)$, Larinia t-notata $(\mathrm{n}=2)$, Acacesia villalobosi $(\mathrm{n}=2)$, Araneus omnicolor $(\mathrm{n}=2)$, Araneus blumenau $(\mathrm{n}=2)$, Wagnerianaeupalaestris $(\mathrm{n}=1)$, Wagneriana iguape $(\mathrm{n}=1)$, Mangora $\mathrm{sp}_{1}(\mathrm{n}=1)$, Alpaida argenta $(\mathrm{n}=1)$ and 657 unidentified juveniles. Members of other spider families included tetragnathids (3 unidentified juveniles), theridiids ( 2 unidentified 
TABLE 2

Comparisons of males and females from the same and from different trap-nest diameters using Mann-Whitney's U test.

\begin{tabular}{|c|c|c|c|c|c|c|}
\hline & $0_{0.7} \times \bigcirc^{\lambda} \mathbf{0 . 7}$ & $\bigcirc \mathbf{0 . 7} \times \bigcirc \mathbf{1 . 0}$ & $q_{0.7} \times \bigcirc^{\lambda} \mathbf{1 . 0}$ & $\mathbf{1 . 0} \times \bigcirc^{\lambda} \mathbf{0 . 7}$ & $q_{1.0} \overbrace{}^{\lambda} \mathbf{1 . 0}$ & $\widehat{\partial} \mathbf{0 . 7} \times \overbrace{}^{\lambda} \mathbf{1 . 0}$ \\
\hline $\begin{array}{c}\text { Development } \\
\text { time (cycle } \\
\text { without } \\
\text { diapause) }\end{array}$ & $\begin{array}{c}\mathrm{U}=9.197 .500 \\
\mathrm{P}=0.042 \\
\mathrm{~N}=282\end{array}$ & $\begin{array}{c}\mathrm{U}=6.726 .000 \\
\mathrm{P}=0.012 \\
\mathrm{~N}=258\end{array}$ & $\begin{array}{c}\mathrm{U}=545.500 \\
\mathrm{P}=0.039 \\
\mathrm{~N}=213\end{array}$ & $\begin{array}{c}\mathrm{U}=2.862 .500 \\
\mathrm{P}=0.000 \\
\mathrm{~N}=132\end{array}$ & $\begin{array}{c}\mathrm{U}=242.000 \\
\mathrm{P}=0.984 \\
\mathrm{~N}=63\end{array}$ & $\begin{array}{c}\mathrm{U}=586.500 \\
\mathrm{P}=0.001 \\
\mathrm{~N}=87\end{array}$ \\
\hline $\begin{array}{c}\text { Development } \\
\text { time (cycle } \\
\text { with diapause) }\end{array}$ & $\begin{array}{c}U=87.500 \\
P=0.582 \\
N=40\end{array}$ & $\begin{array}{c}\mathrm{U}=518.000 \\
\mathrm{P}=0.730 \\
\mathrm{~N}=63\end{array}$ & $\begin{array}{c}U=116.500 \\
P=0.582 \\
N=40\end{array}$ & $\begin{array}{c}U=117.500 \\
P=0.956 \\
N=37\end{array}$ & $\begin{array}{c}\mathrm{U}=242.000 \\
\mathrm{P}=0.984 \\
\mathrm{~N}=63\end{array}$ & $\begin{array}{c}U=26.000 \\
P=0.796 \\
N=14\end{array}$ \\
\hline $\begin{array}{l}\text { Cocoon } \\
\text { volume }\end{array}$ & $\begin{array}{c}\mathrm{U}=3.383 .000 \\
\mathrm{P}=0.000 \\
\mathrm{~N}=158\end{array}$ & $\begin{array}{c}\mathrm{U}=6.183 .500 \\
\mathrm{P}=0.000 \\
\mathrm{~N}=185\end{array}$ & $\begin{array}{c}\mathrm{U}=481.000 \\
\mathrm{P}=0.857 \\
\mathrm{~N}=133\end{array}$ & $\begin{array}{c}\mathrm{U}=1.888 .000 \\
\mathrm{P}=0.000 \\
\mathrm{~N}=93\end{array}$ & $\begin{array}{c}\mathrm{U}=373.500 \\
\mathrm{P}=0.011 \\
\mathrm{~N}=68\end{array}$ & $\begin{array}{c}\mathrm{U}=211.000 \\
\mathrm{P}=0.009 \\
\mathrm{~N}=41\end{array}$ \\
\hline Weight & $\begin{array}{c}\mathrm{U}=9.125 .500 \\
\mathrm{P}=0.000 \\
\mathrm{~N}=242\end{array}$ & $\begin{array}{c}\mathrm{U}=680.000 \\
\mathrm{P}=0.362 \\
\mathrm{~N}=192\end{array}$ & * & $\begin{array}{c}\mathrm{U}=314.000 \\
\mathrm{P}=0.001 \\
\mathrm{~N}=62\end{array}$ & $*$ & $*$ \\
\hline Cell volume & $\begin{array}{c}\mathrm{U}=6.971 .500 \\
\mathrm{P}=0.040 \\
\mathrm{~N}=260\end{array}$ & $\begin{array}{c}\mathrm{U}=12.667 .500 \\
\mathrm{P}=0.000 \\
\mathrm{~N}=267\end{array}$ & $\begin{array}{c}\mathrm{U}=37.500 \\
\mathrm{P}=0.000 \\
\mathrm{~N}=209\end{array}$ & $\begin{array}{c}\mathrm{U}=3.747 .500 \\
\mathrm{P}=0.000 \\
\mathrm{~N}=125\end{array}$ & $\begin{array}{c}\mathrm{U}=234.500 \\
\mathrm{P}=0.608 \\
\mathrm{~N}=74\end{array}$ & $\begin{array}{c}\mathrm{U}=462.000 \\
\mathrm{P}=0.000 \\
\mathrm{~N}=67\end{array}$ \\
\hline
\end{tabular}

*Sample size too small to allow meaningful statistical tests.

TABLE 3

Development time (days) in both cycle types, cocoon volume and weight of females and males in 0.7 - and 1.0 cm-trap-nests.

\begin{tabular}{|c|c|c|c|c|}
\cline { 2 - 5 } \multicolumn{1}{c|}{} & \multicolumn{2}{c|}{$\mathbf{0 . 7}$} & \multicolumn{2}{c|}{ 1.0 } \\
\cline { 2 - 5 } \multicolumn{1}{c|}{} & Females & Males & Females & Males \\
\hline $\begin{array}{c}\text { Direct } \\
\text { development } \\
\text { (without } \\
\text { diapause) }\end{array}$ & $\overline{\mathrm{X}}=44.8 \pm 7.6$ & $\overline{\mathrm{X}}=42.4 \pm 7.1$ & $\overline{\mathrm{X}}=46.2 \pm 11.2$ & $\mathrm{X}=48.9 \pm 3.0$ \\
$\mathrm{~N}=204$ & $\mathrm{~N}=78$ & $\mathrm{~N}=54$ \\
Median $=45.0$ & Median $=43.0$ & Median $=48.0$ & Median $=49.0$ \\
\hline $\begin{array}{c}\text { Delayed } \\
\text { development } \\
\text { (with diapause) }\end{array}$ & $\overline{\mathrm{X}}=228.4 \pm 35.0$ & $\mathrm{X}=234.4 \pm 21.9$ & $\overline{\mathrm{X}}=232.6 \pm 26.7$ & $\mathrm{X}=238.3 \pm 1.3$ \\
\hline Cocoon volume & $\mathrm{N}=34$ & $\mathrm{~N}=8$ & $\mathrm{~N}=29$ & $\mathrm{~N}=6$ \\
& $\overline{\mathrm{X}}=110.13 \pm 19.12$ & $\overline{\mathrm{X}}=89.02 \pm 17.25$ & $\overline{\mathrm{X}}=132.61 \pm 18.07$ & $\overline{\mathrm{X}}=111.60 \pm 21.39$ \\
& $\mathrm{~N}=125$ & $\mathrm{~N}=33$ & $\mathrm{~N}=60$ & $\mathrm{~N}=8$ \\
& Median $=12.21$ & Median $=86.45$ & Median $=132.28$ & Median $=112.86$ \\
\hline Weight & $\overline{\mathrm{X}}=0.275 \pm 0.05$ & $\overline{\mathrm{X}}=0.204 \pm 0.04$ & $\overline{\mathrm{X}}=0.264 \pm 0.03$ & $0.210^{*}$ \\
& $\mathrm{~N}=186$ & $\mathrm{~N}=56$ & $\mathrm{~N}=6$ & \\
& Median $=0.278$ & Median $=0.206$ & Median $=0.257$ & \\
\hline
\end{tabular}

*Only one male was available.

juveniles), salticids (2 unidentified juveniles) and an anyphaenid (Sonagasta sp. $(\mathrm{n}=1)$ ).

\section{DISCUSSION}

Trypoxylon opacum occurred exclusively in open, sunny areas at "Parque Municipal das Araucárias". Although grasslands are located above the swamp area, both environments were exposed to high insolation, showing higher temperatures and lower humidity than the Araucaria Forest (Fig. 6).

Nesting in Trypoxylon opacum was most frequent in the spring in the first sampling period and in the summer in the second period of this study, and in both periods, wasps entered diapause throughout the winter (a result consistent with a previous study on T. opacum in Southeastern Brazil by Perez-Maluf (1993)). Camillo et al. (1995) 
observed that, regardless of the type of habitat, most nesting for some wasp species occurred in the warm and wet season (September and April) in Cajuru (São Paulo state, Southeastern Brazil). Similar results were observed in sphecid species in Itumbiara (Minas Gerais state, Southeastern Brazil) by Assis \& Camillo (1997), in T. rogehoferi also in Cajuru (São Paulo state, Southeastern Brazil) by Camillo et al. (1994) and in T. lactitarse in Guarapuava (Paraná state, South Brazil) by Niesing (2003).

A particularly interesting result in our study was the relationship between the diameter of the trap-nests and how often they were used by T. opacum. During the first sampling period, 24 trap-nests of $1.0 \mathrm{~cm}$ were always maintained in the field and in the swamp areas and had a collection of 50 T. opacum nests. On the other hand, in the second sampling period, 128 trap-nests of $1.0 \mathrm{~cm}$ were available in both habitats and yet only 11 nests were collected, with the vast majority of the T. opacum nests occurring in $0.7 \mathrm{~cm}$ trapnests.

Perez-Maluf (1993) observed that T. opacum built its nests in trap-nests with opening diameters ranging from 0.3 to $0.8 \mathrm{~cm}$, using preferentially trap-nests of 0.4 and $0.5 \mathrm{~cm}$ in an opening diameter. If T. opacum prefers openings of 0.6 or $0.7 \mathrm{~cm}$, why is the number of nestings in trap-nests of $1.0 \mathrm{~cm}$ diameter 4.5 times higher in the first sampling period than during the second period? One possibility is that the availability of smaller openings in these habitats is low and they had no choice, and therefore when $0.7 \mathrm{~cm}$ trap nests were made available they were promptly used. According to Coville (1982), the opening diameter used by solitary wasps is related to their availability in the habitat. Vinson \& Frankie (1991), observed that the preferred opening diameters are uncommon in the case of wasp species that build their nests in pre-existing cavities, potentially limiting their population growth.

Wasps' preferences of opening diameters are also correlated to their body size, never or seldom using openings above a given value (Ficke cited by Aguiar, 2002). This was confirmed by a study by Assis \& Camillo (1997) that showed a match between preferred orifice diameter and body size: small-sized wasps ( $T$. $\mathrm{sp}_{1}$ aff. nitidium and $T$. $\mathrm{sp}_{2}$ aff. nitidium) built their nests more frequently in smaller trap-nests, whereas larger species
(T. lactitarse and T. rogenhorefi) built them in trap-nests with larger diameters.

Another factor that might determine a nesting site choice is competition with other wasps (Garcia, 1993). However, given that T. opacum is one of the most abundant sphecids in the studied region (Buschini, unpublished data) we believe that the availability of nesting sites is the most important factor determining the types of diameter that have been used by it and not the competition with other species. This is further confirmed by the fact that T. opacum was always the most abundant species in the study size regardless of the trap-nest used.

The total nest length was not significantly different in both nests types. According to S. T. Amarante (personal communication), wood trapnests commonly used in studies of wasp natural history have limited depth, possibly distorting conclusions regarding variation in nest architecture. We believe that this was not the case in our study, given that the median nest length was 6.7 and $6.4 \mathrm{~cm}$ in 0.7 and $1.0 \mathrm{~cm}$ trap-nests, respectively, indicating that these wasps did not use all of their available nesting space. Moreover, even though the trap-nests in the present study had an inner cavity of $8 \mathrm{~cm}$ in depth, T. opacum nests have a total number of cells ranging from 1 to 8 in both types of trap-nests. This is further evidence that the nests observed in our study are similar to those in more natural conditions.

Camillo \& Brescovit (1999) observed that T. lactitarse and T. rogenhoferi used trap-nests with a length of 9.1-1.1 cm and 9.1-10.0 cm, respective1y. Cell number in these nests ranged from 3 to 9 for T. lactitarse and from 1 to 9 for T. rogenhoferi. Perez-Maluf (1993) found in T. opacum nests with 2 to 6 provisioned cells, with 1 to 3 vestibular cells and with 1 to 3 intercalar cells. No intercalar cells were observed in $T$. opacum nests. The number of provisioned cells ranged from 1 to 8 and the number of vestibular cells ranged from 1 to 2 in the largest trap-nests. In $0.7 \mathrm{~cm}$-trap-nests, the number of provisioned cells ranged from 1 to 7 and the number of vestibular cells ranged from 1 to 5 . It is worth noting that, even though the number of provisioned cells was significantly larger in $1.0 \mathrm{~cm}$-trap-nests, their length was significantly shorter than those in $0.7 \mathrm{~cm}$-trap-nests.

The body weight was markedly different between males and females of T. opacum. Females from nests with different diameters had similar 
weights, but the volumes of their cocoons and cells were significantly different. Several authors have observed a significant relationship between differences in the weight of different sexes and their cells, as well as the length of their cocoons (Brockmann \& Grafen 1992; Camillo et al., 1996; Camillo \& Brescovit, 1999). Other studies failed to show this relationship (Camillo et al., 1993; Camillo et al., 1994; Assis \& Camillo, 1997), where the only statistically significant difference was between females and males from different types of trap-nests (but not within the same type of trap-nest).

The cocoon structure of $T$. opacum was similar to that described by Perez-Maluf (1993) in T. opacum and by Coville (1981) in T. clavatum. Although the cocoon volume was significantly different among trap-nests, this difference did not affect the morphology of the cocoon in either sex.

Camillo et al., (1993) found that females of T. lactitarse are more common in the outer cells of the nest, whereas males were more common in the inner cells. This spatial segregation was not found in the present study, as well as in other species of Trypoxylon (Assis \& Camillo, 1997), including T. nitidium (Coville, 1981) and T. lactitarse (Niesing, 2003).

Two types of larval development were observed in T. opacum in the present study: direct development, where larvae (prepupae) pupate immediately and emerge later in the summer; or delayed development through a period of diapause, with emergence being postponed until the following spring. These types of development were also observed by Camillo et al., (1993) in T. rogenhoferi, by Brockmann \& Grafen (1992) in T. politum and by Niensing (2003) in T. lactitarse. Diapause is a strategy used by some species of wasps to cope with adverse climatic conditions, particularly as a response to low food availability (Camillo et al., 1996). Although the spiders used by Trypoxylon do not enter diapause (A. Brescovit, personal communication), the availability of food and low air temperatures in Guarapuava during the winter could be the factors favoring diapause in these insects. Given that Guarapuava is located in a subtropical region and is considered one of the coldest cities in Parana state, many spiders may die under this condition and, consequently, decrease the availability of prey.
The numerical sex ratio found by Perez-Maluf (1993) for T. opacum was 0.37 females to 1 male, not significantly different from 1:1. In our research, the number of females was significantly higher than the number of males. As this is quite unexpected, these data need to be investigated in more detail. It should be mentioned that studies concerning sex allocation and the behavior of T. opacum in this region have already begun.

Mortality rates were higher in $1.0 \mathrm{~cm}$ than in $0.7 \mathrm{~cm}$ trap-nests. These rates were higher than those found by Perez-Maluf (1993) in T. opacum, where developmental failures accounted for most of the deaths. In the present study, we observed a similar effect in the case of $1.0 \mathrm{~cm}$ trap-nests. However, this was not the case in $0.7 \mathrm{~cm}$ trap-nests, where the most important cause of mortality was due to parasitoids, particularly chrysidids.

Jayasingh \& Taffe (1982) suggested that cells that are close to the nest entrance should have higher rates of mortality due to natural enemies because of their greater exposure. Higher parasitism rates in outer cells were found in both T. lactitarse (Camillo et al., 1993) and T. rogenhoferi (Camillo et al., 1994). This pattern was not observed in the present study, where, even though attacks by chrysidids accounted for $35.65 \%$ of the mortality in $0.7 \mathrm{~cm}$ trap-nests, the spatial distribution of their attacks seems random. Attacks by sarcophagids accounted for $21.45 \%$ of the mortality in $0.7 \mathrm{~cm}$ trap-nests and for $33.33 \%$ in $1.0 \mathrm{~cm}$ trap-nests. Even when Sarcophagidae eggs were laid in the outer cells, their larvae perforated the mud partitions of all the inner cells and killed all the wasp larvae.

According to Perez-Maluf (1993), the female strategy of laying male eggs in cells that are closest to the nest entrance and female eggs in the innermost cells could be a response to the behavior of the parasitoid species that enter nests by their entrance, causing outer cells to be more heavily parasitized. Given that sons are less costly to produce than the daughters, their position in the outer cells should decrease the investment lost by the female founder. In the case of T. opacum, there was no difference in attack rates between cells according to their spatial position. Therefore, the selective pressure favoring the spatial segregation of larvae would be absent, which would explain our results. Another explanation for cell placement in wasps is their development time. Since males have 
a shorter development than females, they emerge earlier than females and thus allow females to go through (with longer development) from inner cells. Hamilton (1972) proposed that Trypargilum females randomly place male and female cells to deceive males who guard the nests to make them stay in the nest to assure the paternity of their daughters. I believe that this is the best explanation for this paper data since I started to study T. opacum nesting behavior and the males always guard their nests (Buschini, unpublished data).

Acknowledgments - Partial financial support was provided by the Fundação Araucária (The State of Paraná Research Foundation) and UNICENTRO (Guarapuava -PR, Brazil). We would like to thank Prof. Dr. Miguel Petrere Jr. from UNESP (Rio Claro-SP) for the statistical discussion. We would also like to thank Prof. Dr. Antônio D. Brescovit from the Instituto Butantan (SP) for the identification of the spiders, Prof. Dr Sérvio Túlio Amarante from Museu de Zoologia da USP (SP) for the identification of the wasps, Profa Dra Angélica Maria P. Martins Dias from UFSCAR (SP) for identifying the Ichneumonidae, Prof. Dr. Rogério Pincela Mateus from UNICENTRO (PR) for reviewing an earlier version of the manuscript and Prof. Ms Sérgio Bazílio from UNICENTRO (PR, Brazil) for some help.

\section{REFERENCES}

AGUIAR, A. J. C., 2002, Abelhas e vespas solitárias em ninhosarmadilha na Reserva Biológica Guaribas (Mamanguape, Paraíba, Brasil). Revta Bras. Zool., 19(Supl. 1): 101-116.

ASSIS, J. M. F. \& CAMILlO, E., 1997, Diversidade, sazonalidade e aspectos biológicos de vespas solitárias (Hymenoptera: Sphecidae: Vespidae) em ninhos armadilhas na Região de Ituiutaba, MG. An. Soc. Entomol. Brasil, 26(2): 335-347.

BOHART, R. M. \& MENKE, A. S., 1976, Sphecid Wasps of World, a Generic Revision. University of California, U.S.A..

BROCKMANN, H. J. \& GRAFEN, A., 1992, Sex ratios and life-history patterns of a solitary wasp, Trypoxylon (Trypargilum) politum (Hymenoptera: Sphecidae). Behav. Ecol. Sociobiol., 30: 7-27.

CAMillo, E., GAROFAlO, C. A., MuCCillo, G. \& SERRANO, J. C., 1993, Biological observations on Trypoxylon (Trypargilum) lactitarse Saussure in southeastern Brazil (Hymenoptera: Sphecidae). Rev.. Bras. Entomol., 37(4): 769-778.

CAMILlO, E., GAROFALO, C. A. \& SERRANO, J. C., 1994, Observações sobre a biologia de Trypoxylon (Trypargilum) rogenhoferi Kohl (Hymenoptera: Sphecidae). An. Soc. Entomol. Brasil, 23(2): 299-309.

CAmillo, E., GAROFAlO, C. A., ASSis, J. M. F. \& SERRANO, J. C., 1996, Biologia de Podium denticulatum Smith em ninhos armadilhas (Hymenoptera: Sphecidae: Sphecinae). An. Soc. Entomol. Brasil, 25(3): 439-449.

CAMILlO, E. \& BRESCOVIT, A. D., 1999, Aspectos biológicos de Trypoxylon (Trypargilum) lactitarse
Saussure e Trypoxylon (Trypargilum) rogenhoferi Kohl (Hymenoptera: Sphecidae) em ninhos-armadilhas, com especial referência a suas presas. An Soc. Entomol. Brasil, 28(2): 251-261.

CAMILlo, E. \& BRESCOVIT, A. D., 2000, Spider prey (Araneae) of Trypoxylon (Trypargilum) rogenhoferi (Hymenoptera: Sphecidae) in southeastern Brazil. Rev. Biol. Trop., 48 (2-3): 647-656.

COVILLE, R. E., 1981, Biological observations on three Trypoxylon wasps in the subgenus Trypargilum from Costa Rica: T. nitidum schulthessi, T. sausurei and T. lactitarse (Hymenoptera: Sphecidae). The Pan-Pacific Entomol., 57(2): 332-40.

COVILLE, R. E., 1982, Wasps of the genus Trypoxylon subgenus Trypargilum in the North America. University of California Press, Berkeley.

GARCIA, M. V. B., 1993, Biologia de Trypoxylon (Trypargilum) rogenhoferi kohl (hymenoptera, Sphecidae) e atividade de nidificação de Trypoxylon (Trypargilum) spp. na Amazônia Central. Tese de mestrado. INPA/UFAM, Manaus, AM., $105 \mathrm{p}$.

GARÓFALO, C. A., 2000, Comunidades de abelhas (Hymenoptera, Apoidea) que utilizam ninhos-armadilhas em fragmentos de matas do Cerrado de São Paulo. Ann. IV Encontro sobre Abelhas- Ribeirão Preto, SP, Brasil, 121-128.

GENARO, J. A., SANCHEZ, C. S. \& ALAYÓN, G., 1989, Notas sobre la conducta de nidificación de Trypoxylon (Trypargilum) subimpressum Smith (Hymenoptera: Sphecidae). Caribbean J. Sci., 25: 228-229.

HAMILTON, W. D., 1972, Altruism and related phenomena, mainly in social insects. A. Rev. Ecol. Syst., 3: 193-232.

JAYASINGH, D. B. \& TAFFE, C. A, 1982, The biology of the eumenid mud-wasp Pachodynerus nasidens in trap-nests. Ecol. Entomol. 7: 283-289.

KROMBEIN, K. V., 1967, Trap-nesting wasps and bees: life histories, nests and associates. Smithsonian Press, Washington.

MENKE, A. S. \& FERNÁNDEZ, F., 1996, Claves ilustradas para las subfamilias, tribus y géneros de esfécidos neotropicales (Apoidea: Sphecidae). Rev. Biol. Trop. 44(supl. 2): 1-68.

NEISING, F., 2003, Abundância, Sazonalidade e Aspectos Biológicos de Trypoxylon (Trypargilum) lactitarse (Hymenoptera, Cambronidae) no Parque Municipal das Araucárias, Guarapuava-PR. Guarapuava. Monograph, Universidade Estadual do Centro-Oeste, Guarapuava, Paraná, Brasil.

PÉREZ-MALUF, R., 1993, Biologia de vespas e abelhas solitárias, em ninhos-armadilhas, em Viçosa - MG. M. S. thesis, Universidade Federal de Viçosa, Viçosa, Minas Gerais, Brasil.

VINSON , S. B \& FRANKIE, G. W., 1991, Nest variability in Centris aethyctera Hymenoptera; Anthophoridae) in response to nesting conditions. Jour. Kans.Entomol. Soc. 60(2): 249-263. 
